Article

\title{
In Vitro Bioassay-Guided Identification of Anticancer Properties from Moringa oleifera Lam. Leaf against the MDA-MB-231 Cell Line
}

\author{
Prapakorn Wisitpongpun ${ }^{1}$, Nungruthai Suphrom ${ }^{2}$, Pachuen Potup ${ }^{1}$, Nitra Nuengchamnong ${ }^{3}$, \\ Philip C. Calder ${ }^{4}(\mathbb{D}$ and Kanchana Usuwanthim $1, * \mathbb{D}$ \\ 1 Cellular and Molecular Immunology Research Unit (CMIRU), Faculty of Allied Health Sciences, \\ Naresuan University, Phitsanulok 65000, Thailand; prapakornw59@nu.ac.th (P.W.); pachuenp@nu.ac.th (P.P.) \\ 2 Department of Chemistry, Faculty of Science and Center of Excellence for Innovation in Chemistry, \\ Naresuan University, Phitsanulok 65000, Thailand; nungruthais@nu.ac.th \\ 3 Science Laboratory Centre, Faculty of Science, Naresuan University, Phitsanulok 65000, Thailand; \\ Nitran@nu.ac.th \\ 4 School of Human Development and Health, Faculty of Medicine, University of Southampton, \\ Southampton SO166YD, UK; pcc@southampton.ac.uk \\ * Correspondence: kanchanau@nu.ac.th; Tel.: +66-89-780-3878
}

Received: 12 October 2020; Accepted: 4 December 2020; Published: 15 December 2020

check for updates

\begin{abstract}
Moringa oleifera Lam. (MO) is a medicinal plant distributed across the Middle East, Asia, and Africa. MO has been used in the traditional treatment of various diseases including cancer. This study aimed to perform bioassay-guided fractionation and identification of bioactive compounds from MO leaf against MDA-MB-231 breast cancer cells. MO leaf was sequentially extracted with hexane, ethyl acetate (EtOAc), and ethanol. The most effective extract was subjected to fractionation. MO extract and its derived fractions were continuously screened for anti-cancer activities. The strongest fraction was selected for re-fractionation and identification of bioactive compounds using LC-ESI-QTOF-MS/MS analysis. The best anticancer activities were related to the fraction no. 7-derived crude EtOAc extract. This fraction significantly reduced cell viability and clonogenic growth and increased cells apoptosis. Moreover, sub-fraction no. 7.7-derived fraction no. 7 was selected for the identification of bioactive compounds. There were 10 candidate compounds tentatively identified by LC-ESI-QTOF-MS. Three of identified compounds (7-octenoic acid, oleamide, and 1-phenyl-2-pentanol) showed anticancer activities by inducing cell cycle arrest and triggering apoptosis through suppressed Bcl-2 expression which subsequently promotes activation of caspase 3, indicators for the apoptosis pathway. This study identified 10 candidate compounds that may have potential in the field of anticancer substances.
\end{abstract}

Keywords: Moringa oleifera; triple negative breast cancer; MDA-MB-231; oleamide; 7-octenoic acid; 1-phenyl-2-pentanol; LC-ESI-QTOF-MS/MS

\section{Introduction}

Breast cancer is the most frequently diagnosed cancer in women and is one of the leading causes of cancer death for women. Worldwide, over 1.3 million cases of invasive breast cancer are diagnosed and more than 450,000 women die from breast cancer annually [1,2]. Breast cancer is a heterogeneous disease with distinct pathological entities and therefore needs diverse therapeutic interventions. Approximately 10-20\% of invasive breast cancers are triple-negative breast cancer (TNBC) which is defined as the absence of estrogen receptor, progesterone receptor, and human epidermal growth factor receptor (HER) 2 [3]. TNBC is associated with poor prognosis, and the survival after metastasis is 
worse compared to other subtypes [3,4]. Unfortunately, due to lack of targeted therapy, radiotherapy and chemotherapy remain the only recommended option for TNBC $[3,5,6]$. Therefore, it is urgent to develop new alternative therapies for TNBC.

Moringa oleifera Lam. (MO) is a highly valued medicinal plant native to India and now distributed widely across the Middle East, Africa, and Asia, including Thailand. It belongs to the family Moringaceae and is commonly referred to as the "Drumstick tree" [7-9]. All parts of the MO possess medicinal properties, and the leaf has the highest nutritional value [10]. MO leaves (MOL) contain high levels of vitamins $C$ and A, potassium, calcium, iron, and proteins. Additionally, the leaves contain phytochemicals like carotenoids, alkaloids, flavonoids, and amino acids, such as cystine, lysine, methionine, and tryptophan [10-12]. In vitro and in vivo studies have demonstrated that MOL extract has various biological activities and therapeutic effects, including cardioprotective [13], hypocholesterolaemic [14], neuroprotective [15], anti-inflammatory [16], antioxidant [17-19], anti-hypertensive [20,21], antidiabetic [22,23], antibacterial [24,25], immunomodulatory [26,27], and anticancer properties [28-30].

With regard to the anticancer properties, MOL extracts have been shown to disrupt the proliferation of different cancer cell lines, for example the hot aqueous MOL extract induced apoptosis in human lung cancer A549 cells by affecting mitochondrial viability in a ROS-dependent manner [29]. It also can induced cell cycle arrest in murine B16F10 melanoma cells by increasing of p53, p21 ${ }^{\mathrm{WAF} 1 / \mathrm{Cip} 1}$ and p27 Kip1 proteins [30]. The methanolic MOL extract induced apoptosis in human cervical cancer HeLa cells by promoting DNA fragmentation [31]. Moreover, oral administration of cold aqueous MOL extract induced apoptosis of human hepatocellular carcinoma HepG2 cells by affecting the apoptosis-related proteins Bcl-2 and caspase-3 [32]. In breast cancer, most of the previous studies of MOL extracts have used the MCF-7 cell line, a hormone receptor-positive breast cancer model [32,33]. Only one study has investigated the effect of MOL on the TNBC cell line, MDA-MB-231: the authors found that ethanol MOL extract arrested these cells at the G2/M phase and effectively induced apoptosis [32]. However, the underlying mechanism and the bioactive compounds involved have not yet been fully elucidated.

In this study, we investigated the in vitro anticancer effect of MOL extract against MDA-MB-231 cells by bioassay-guided fractionation, and identification of potential bioactive compounds responsible for the observed effects. We found that MOL extracts and derived fractions showed a remarkable anticancer activity with a significant decrease of cell viability, striking reduction of colony formation, and induction of apoptosis and cell cycle arrest at the G2/M phase. Additionally, we tentatively identified 10 bioactive compounds by LC-ESI-QTOF-MS analysis. Three of them (7-octenoic acid, oleamide, and 1-phenyl-2-pentanol) can arrest the cell cycle and induce apoptosis of MDA-MB-231 cells. We also demonstrated the anticancer properties of oleamide on human myelogenous leukemia cell K562 and human squamous cell carcinoma SCC-15.

\section{Results}

\subsection{Screening for Cytotoxic Effects of Crude Hexane, EtOAc, and EtOH Extracts of MOL}

To compare the cytotoxic effects of crude MOL extracts, MDA-MB-231 cells were plated into 96-well plates and incubated with serial concentrations of the crude hexane, crude EtOAc, and crude ethanolic $(\mathrm{EtOH})$ extracts for $24 \mathrm{~h}$. Cell viability was assessed using the MTT assay. Crude EtOAc extract exhibited the lowest $\mathrm{IC}_{50}$ value $(233.5 \mu \mathrm{g} / \mathrm{mL})$ followed by crude EtOH extract $(241.1 \mu \mathrm{g} / \mathrm{mL})$, and crude hexane extract $(342.6 \mu \mathrm{g} / \mathrm{mL}$ ), respectively (Figure 1A,B). The crude EtOAc MOL extract was subjected to further fractionation. 

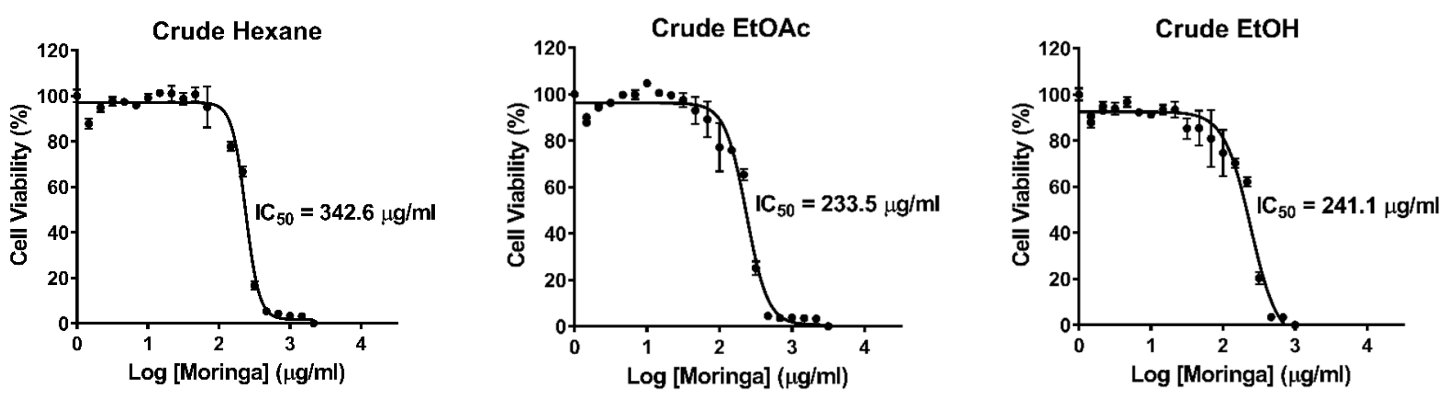

(A)

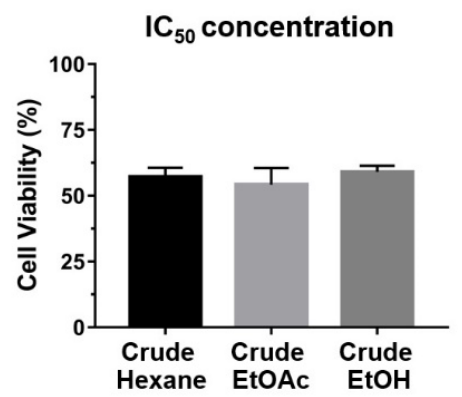

(B)

Figure 1. Effects of crude hexane, EtOAc, and EtOH extracts of MOL on the viability of MDA-MB-231 cells. (A) Cells were plated into 96-well plates and incubated with each extract for $24 \mathrm{~h}$. $\mathrm{IC}_{50}$ values were calculated using GraphPad Prism 6.0 software. Each dot represents mean \pm SEM of three independent experiments. (B) Cell viability after treatment with each extract at $\mathrm{IC}_{50}$ concentrations for $24 \mathrm{~h}$. One-way ANOVA was performed with multiple comparison correction (Dunnett test). Data represent the mean \pm SEM of three independent experiments. IC50, the half-maximal inhibitory concentration; EtOAc, ethyl acetate; $\mathrm{EtOH}$, ethanol.

\subsection{Cytotoxic Effects of EtOAc Extract of MOL and Its Derived Fractions on MDA-MB-231 Cells}

To examine the inhibitory effects of crude EtOAc extract and its derived fractions, MDA-MB-231 cells were incubated with crude EtOAc extract and fractions no. 1-11 at concentrations of 75, 100, and $150 \mu \mathrm{g} / \mathrm{mL}$ for $24 \mathrm{~h}$. Cell viability was determined using the MTT assay (Figure 2A). Cell viability was significantly decreased after treatment with crude EtOAc extract and fractions no. 5-8 and 10-11. There was a noticeable difference with fractions no. 6-8 showing a significant decrease in cell viability in a dose-dependent manner. The fraction no. 7 showed the strongest cytotoxicity, and thus this fraction was investigated further at different times points (Figure 2B). Cell viability was significantly decreased in time-dependent manner after treatment with $100 \mu \mathrm{g} / \mathrm{mL}$ of fraction no.7. As fractions no. 6-8 exhibited notable effects on viability, we further investigated the impact of crude EtOAc extract and fractions no. 6-8 on the clonogenic growth of MDA-MB-231 cells (Figure 2C and Figure S1). Cells were incubated with crude EtOAc extract or fractions no. 6-8 for $24 \mathrm{~h}$. After incubation, cells were cultured for 14 days in complete medium and then stained with crystal violet to visualize the colonies. Fractions no. 6-8 at concentrations $50-150 \mu \mathrm{g} / \mathrm{mL}$ showed a significant reduction in the number of colonies. These results suggest that the clonogenic growth of MDA-MB-231 cells was completely inhibited by fractions no. $6-8$ of MOL extract. 


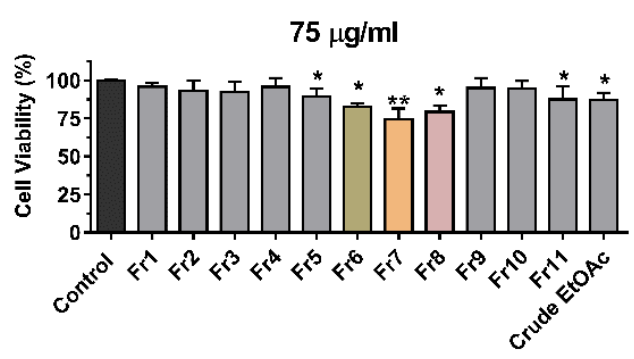

$100 \mu \mathrm{g} / \mathrm{ml}$

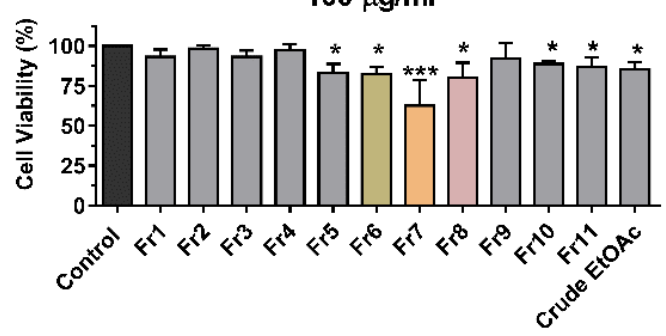

$150 \mu \mathrm{g} / \mathrm{ml}$

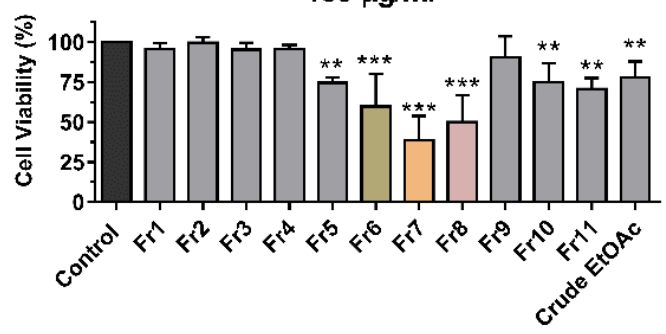

(A)

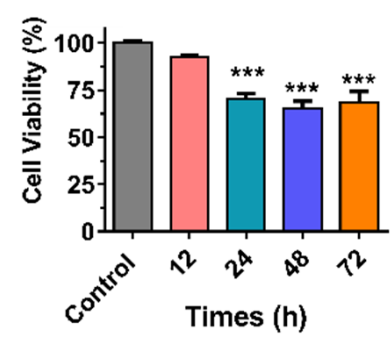

(B)

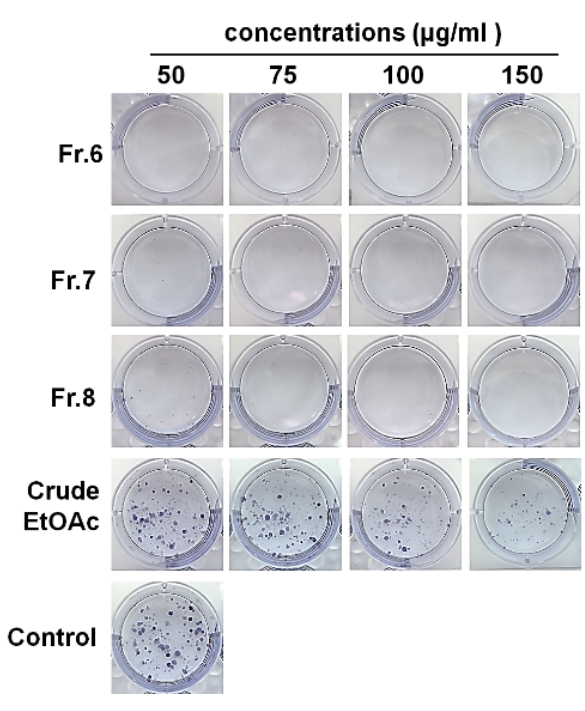

(C)

Figure 2. Cytotoxic effect of EtOAc extract and its derived fractions on MDA-MB-231 cells. (A) Cells were treated with crude EtOAc extract and fractions no.1-11 at concentrations 70, 100, and $150 \mu \mathrm{g} / \mathrm{mL}$ for $24 \mathrm{~h}$. (B) Cells were treated with $100 \mu \mathrm{g} / \mathrm{mL}$ of fraction no. 7 in various times. (C) Colony formation assay. One-way ANOVA was performed with multiple comparison correction (Dunnett test). Data represent the mean \pm SEM of three independent experiments. $\left({ }^{*} p<0.05,{ }^{* *} p<0.01,{ }^{* * *} p<0.001\right)$. EtOAc, ethyl acetate; Fr, fraction.

\subsection{Effect of Crude EtOAc Extract and Fractions No. 6-8 on MDA-MB-231 Cell Apoptosis and Cell-Cycle Arrest}

To evaluate the role of crude EtOAc extract and fractions no. 6-8 on cell apoptosis and cell-cycle regulation, MDA-MB-231 cells were incubated with crude EtOAc extract and fractions no. 6-8 $(150 \mu \mathrm{g} / \mathrm{mL})$ for $24 \mathrm{~h}$. After incubation, cells were stained with Annexin V/7-AAD and analyzed by a Muse cell analyzer (Merck KGaA, Darmstadt, Germany) (Figure 3A,B and Figure S2). Crude EtOAc extract and fractions no. 6-8 significantly increased the proportion of late apoptotic cells up to 16.0, 23.9, 44.2 , and $39.8 \%$, respectively. The proportion of dead cells also increased to $43.6,75.8,54.2$, and $60.1 \%$, respectively. In addition, the alteration of the cell-cycle distribution was also analyzed (Figure 3C,D and Figure S3). Treatment with fractions no. 6 and 8 resulted in the accumulation of cells at the G0/G1 phase. This varied from $53.5 \%$ (control) to $61.8 \%$ and $63.4 \%$, respectively. Fraction no. 7 resulted in the accumulation of cells at the G2/M phase (from $26.2 \%$ to $38.4 \%$ ). Therefore, these results suggest that fractions no. 6-8 promoted cell cycle arrest and induced apoptosis of MDA-MB-231 cells. 


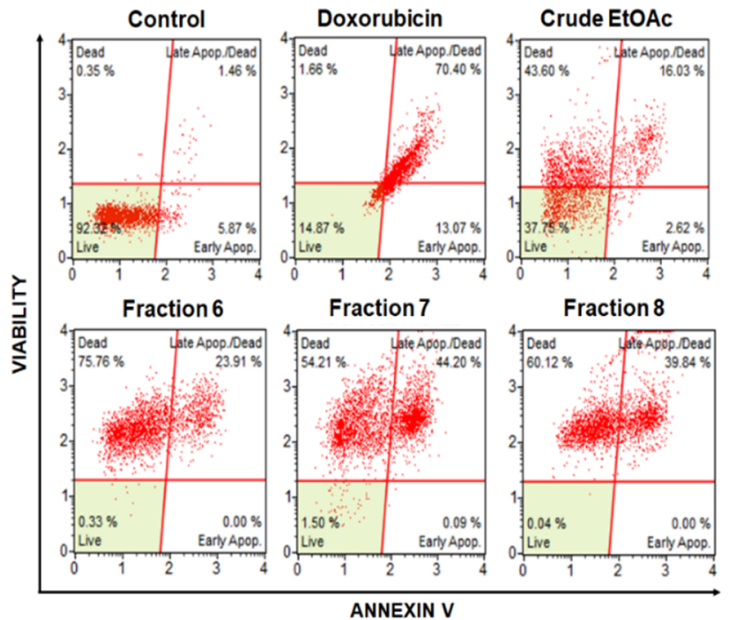

(A)

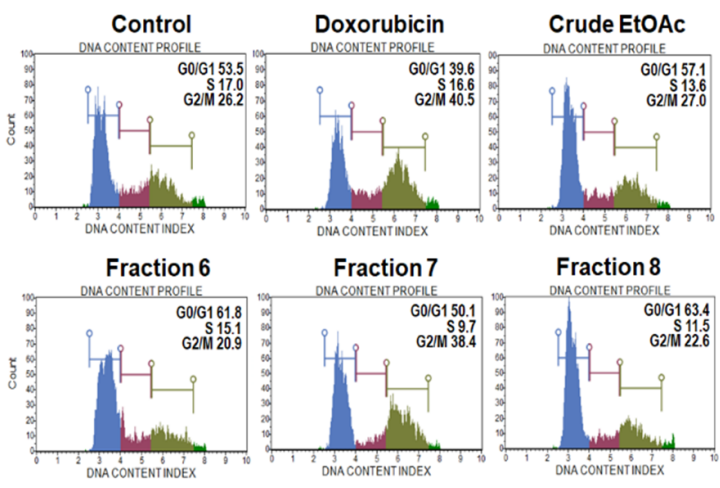

(C)

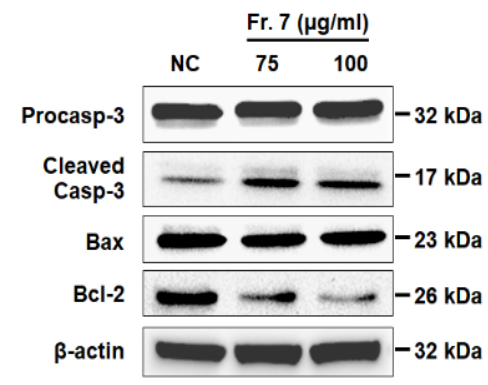

(E)

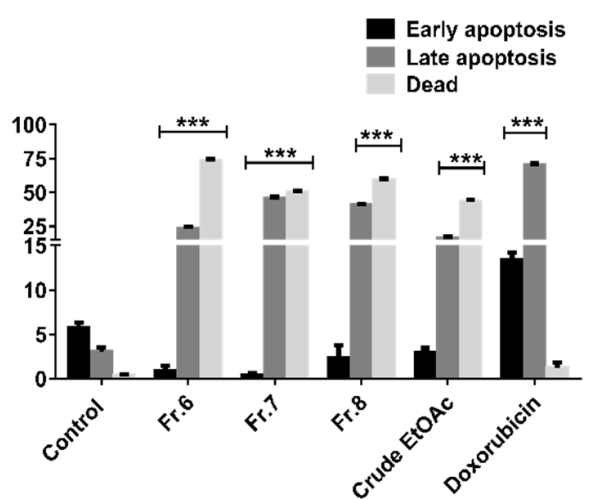

(B)

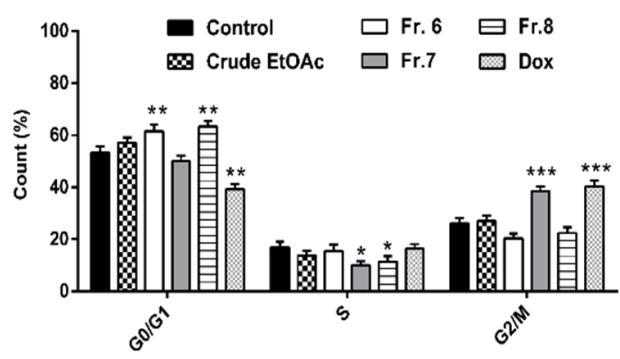

(D)

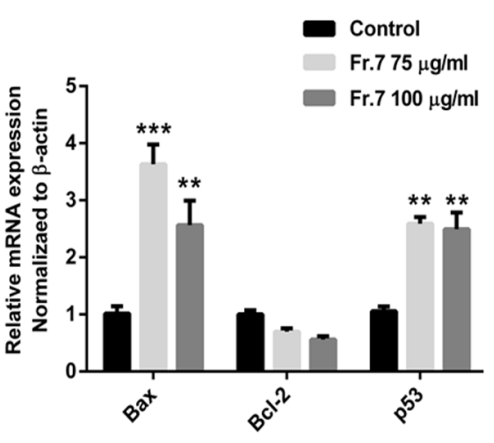

(F)

Figure 3. Effect of crude EtOAc extract and fractions no. 6-8 on MDA-MB-231 cell apoptosis and cell-cycle arrest. (A-D) Cell apoptosis and cell cycle progression analyzed by using Muse cell analyzer. Cells were incubated with crude EtOAc extract or fractions no. 6-8 at $150 \mu \mathrm{g} / \mathrm{mL}$ for $24 \mathrm{~h}$. For untreated control, cells were incubated with complete medium alone. For positive control, cells were incubated with doxorubicin $(1.5 \mu \mathrm{M})$. (E) Western blot analysis. (F) mRNA expression by RT-PCR. Cells were incubated with fraction no. 7 for $24 \mathrm{~h}$. One-way ANOVA was performed with multiple comparison correction (Dunnett test). Data represent the mean \pm SEM of three independent experiments. $\left({ }^{*} p<0.05\right.$, $\left.* * p<0.01,{ }^{* * *} p<0.001\right)$. EtOAc, ethyl acetate; Fr, fraction; Dox, doxorubicin; NC, negative control; Fr, fraction; $\beta$-actin, beta-actin. 
Since active fraction no. 7 exhibited the strongest anticancer activities, we further investigated the expression of apoptosis-related proteins and mRNA (Figure 3E,F). The expression of certain pro-apoptotic markers, including cleaved caspase 3 protein, Bax mRNA, and p53 mRNA were significantly increased while anti-apoptotic Bcl-2 protein was decreased by fraction no. 7 treatment. These results suggest that the apoptosis induction by MOL fraction no. 7 is through the inhibition of Bcl-2 and the activation p53, Bax, and caspase 3.

\subsection{Sub-Fractionation of Fraction Bo. 7 and Identification of Compounds by LC-ESI-QTOF-MS/MS}

To separate the different chemical components in active fraction no. 7, we next re-fractionated fraction no. 7 using silica gel column chromatography. Eight sub-fractions (no. 7.1-7.8) were obtained and their cytotoxicity against MDA-MB-231 cells was assessed using MTT assay (Figure S4). Sub-fraction no. 7.7 strongly reduced the viability of MDA-MB-231 cells compared to the other sub-fractions. Thus, we attempted to tentatively identify the bioactive compounds from sub-fraction no 7.7 using LC-ESI-QTOF-MS/MS. This sub-fraction was injected into an Agilent 1260 Infinity series HPLC system and the constituents were collected in a 96-well plate with 30 s per well until $33 \mathrm{~min}$. In total, ten candidate compounds (C1-C10) were identified. All collected samples were screened for cytotoxicity using the MTT assay and the acquisition times represented active compounds between of 10.414 (C1), 12.286 (C2), 17.586 (C3), 20.198 (C4), 21.015 (C5), 22.476 (C6), 26.473 (C7), 30.557 (C8), 32.057 (C9), and 32.606 (C10) $\min$ (Figure 4 and Figure S5). The full tentative identification is listed in Table 1.

\subsection{The Role of Three-Identified Compounds, 7-Octenoic Acid, Oleamide, and 1-Phenyl-2-Pentanol on MDA-MB-231 Cells Apoptosis and Cell Cycle Progression}

Cytotoxicity of compounds on MDA-MB-231 cells was measured by incubating with serial concentrations of 7-octenoic acid, cis-9-octadeceneamide (oleamide), and 1-phenyl-2-pentanol for $24 \mathrm{~h}$ (Figure S6). The result showed that cytotoxic dose of oleamide was less than both 1-phenyl-2-pentanol and 7-octenoic acid. To determine the anticancer effect of compounds, we examined the morphologic changes by Hoechst 33342 staining (Figure 5A). An apoptotic morphology was observed after treatments with 7-octenoic acid, oleamide, and 1-phenyl-2-pentanol for $24 \mathrm{~h}$, whereas control cells were round and homogeneously stained. Then apoptosis was assessed by AnnexinV/7-AAD staining with Muse cell analyser (Figure 5B,C). Treatment with 7-octenoic acid significantly increased the proportion of late apoptotic cells. Oleamide and 1-phenyl-2-pentanol significantly increased the proportion of both early and late apoptotic cells. Moreover, the expression of apoptotic-associated proteins; Bcl-2, Bax, pro-caspase 3, and cleaved caspase-3 were measured by Western blot (Figure 5D). We observed an increase of cleaved caspase- 3 with the decrease of Bcl-2 in cells treated with the compounds. Additionally, Muse cell analyzer indicated cell cycle arrest (Figure 5E,F). The accumulation of cells in the G0/G1 phase was significantly increased in oleamide treated cells, while 7-octenoic acid and 1-phenyl-2-pentanol resulted in the accumulation of cells at the G2/M phase. These results suggested that the three-identified compounds, 7-octenoic acid, oleamide, and 1-phenyl-2-pentanol, can induce cell cycle arrest and apoptosis of MDA-MB-231 cells.

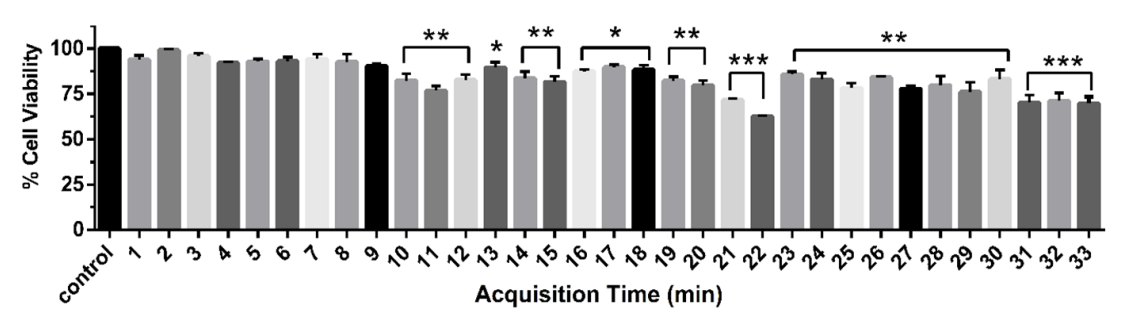

(A)

Figure 4. Cont . 


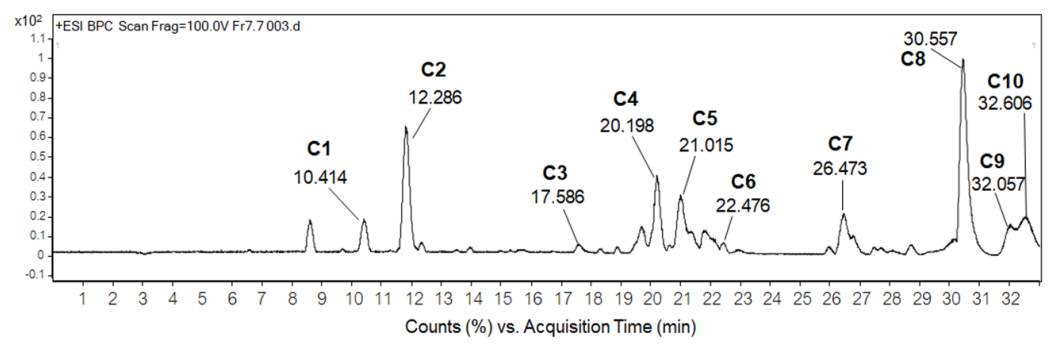

(1) 2-(benzyloxy) butane-1,4-diol

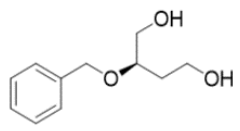

(3) 1-Phenyl-2-pentanol

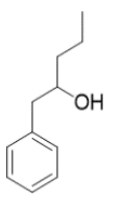

(5) Chrysobalanic acid

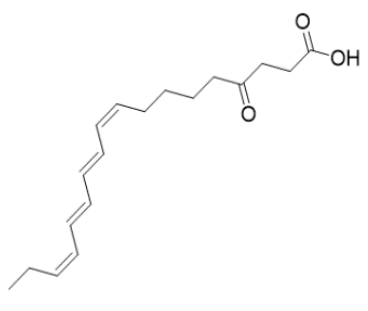

(7) 3E,9Z,12Z,15Z-Octadecatetraenoic acid

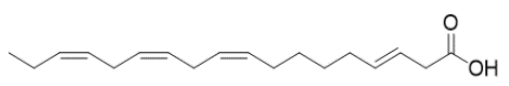

(9) N-(11Z-eicosaenoyl)-ethanolamine

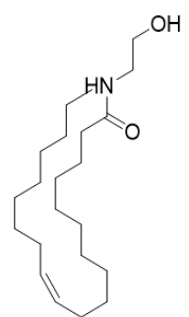

(2) 7-octenoic acid

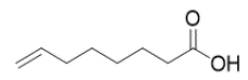

(4) 8-oxo-9,11-octadecadiynoic acid

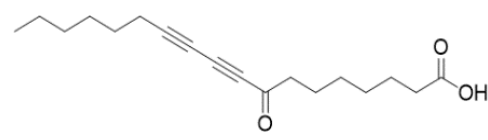

(6) 12-oxo-14,18-dihydroxy-9Z,13E,15Zoctadecatrienoic acid

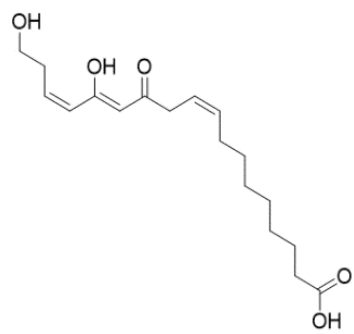

(8) 13,14-dihydroxydocosanamide<smiles>CCCCCCCCC(O)C(O)CCCCCCCCCCCC(N)=O</smiles>

(10) 9Z-octadecenamide

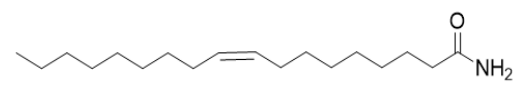

(B)

Figure 4. Cytotoxic effect and LC-ESI-QTOF-MS/MS analysis of compounds from sub-fraction no. 7.7. (A) Cell viability of MDA-MB-231 cells after treatment with each eluted compound for $24 \mathrm{~h}$. (B) LC-ESI-QTOF-MS/MS chromatogram and the identified compounds (C1-C10). One-way ANOVA test was performed with multiple comparison corrections (Dunnett test). Data represent the mean \pm SEM of three independent experiments. $\left.{ }^{*} p<0.05,{ }^{* *} p<0.01,{ }^{* * *} p<0.001\right)$. 
Table 1. Tentative identification of bioactive compounds identified in sub-fraction 7.7 of MOL extract by LC-ESI-QTOF-MS.

\begin{tabular}{|c|c|c|c|c|c|c|}
\hline No. & RT (min) & $\mathrm{m} / \mathrm{z}[\mathbf{M}+\mathbf{H}]+$ & MS/MS & Tentative Identification & Formula & Error (ppm) \\
\hline $\mathrm{C} 1$ & 10.414 & 197.1166 & $\begin{array}{l}179.1015, \\
161.0911, \\
135.1127 \\
107.0822\end{array}$ & 2 -(benzyloxy) butane-1,4-diol & $\mathrm{C}_{11} \mathrm{H}_{16} \mathrm{O}_{3}$ & 3.15 \\
\hline $\mathrm{C} 2$ & 12.286 & 143.1057 & $\begin{array}{c}128.0550, \\
101.0912, \\
83.0814 \\
62.9783 \\
59.0458 \\
55.0513\end{array}$ & 7-octenoic acid & $\mathrm{C}_{8} \mathrm{H}_{14} \mathrm{O}_{2}$ & 6.68 \\
\hline C3 & 17.586 & 165.1272 & $\begin{array}{c}\text { 147.1157, } \\
95.0482\end{array}$ & 1-Phenyl-2-pentanol & $\mathrm{C}_{11} \mathrm{H}_{16} \mathrm{O}$ & 1.16 \\
\hline $\mathrm{C} 4$ & 20.198 & 291.1955 & 273.1828 & 8-oxo-9,11-octadecadiynoic acid & $\mathrm{C}_{18} \mathrm{H}_{26} \mathrm{O}_{3}$ & -0.79 \\
\hline C5 & 21.015 & 291.1958 & $\begin{array}{l}\text { 273.1806, } \\
171.1019\end{array}$ & 4-oxo-octadeca-9Z,11E,13E,15Z-tetraenoic acid, Chrysobalanic acid & $\mathrm{C}_{18} \mathrm{H}_{26} \mathrm{O}_{3}$ & -1.13 \\
\hline C6 & 22.476 & 325.2013 & $\begin{array}{l}291.1925 \\
233.1518 \\
137.0949\end{array}$ & 12-oxo-14,18-dihydroxy-9Z,13E,15Z-octadecatrienoic acid & $\mathrm{C}_{18} \mathrm{H}_{28} \mathrm{O}_{5}$ & -1.08 \\
\hline C7 & 26.473 & 277.2148 & $\begin{array}{c}135.1125 \\
93.0669 \\
79.0517\end{array}$ & 3E,9Z,12Z,15Z-Octadecatetraenoic acid & $\mathrm{C}_{18} \mathrm{H}_{28} \mathrm{O}_{2}$ & 5.09 \\
\hline $\mathrm{C} 8$ & 30.557 & 372.3457 & $\begin{array}{c}354.3303 \\
337.3052 \\
319.2933 \\
97.0993 \\
83.0840\end{array}$ & 13,14-dihydroxydocosanamide & $\mathrm{C}_{22} \mathrm{H}_{45} \mathrm{NO}_{3}$ & 2.75 \\
\hline C9 & 32.057 & 354.3379 & $\begin{array}{l}337.3075 \\
319.2965 \\
301.2865\end{array}$ & N-(11Z-eicosaenoyl)-ethanolamine & $\mathrm{C}_{22} \mathrm{H}_{43} \mathrm{NO}_{2}$ & -3.51 \\
\hline $\mathrm{C} 10$ & 32.606 & 282.2784 & * & 9Z-octadecenamide & $\mathrm{C}_{18} \mathrm{H}_{35} \mathrm{NO}$ & 2.63 \\
\hline
\end{tabular}




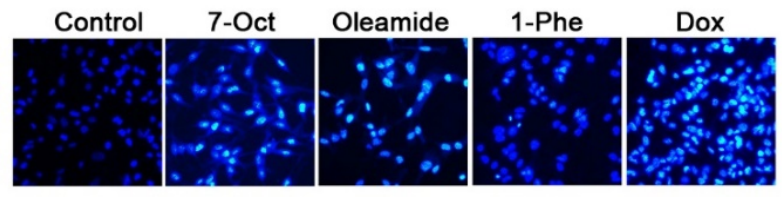

(A)

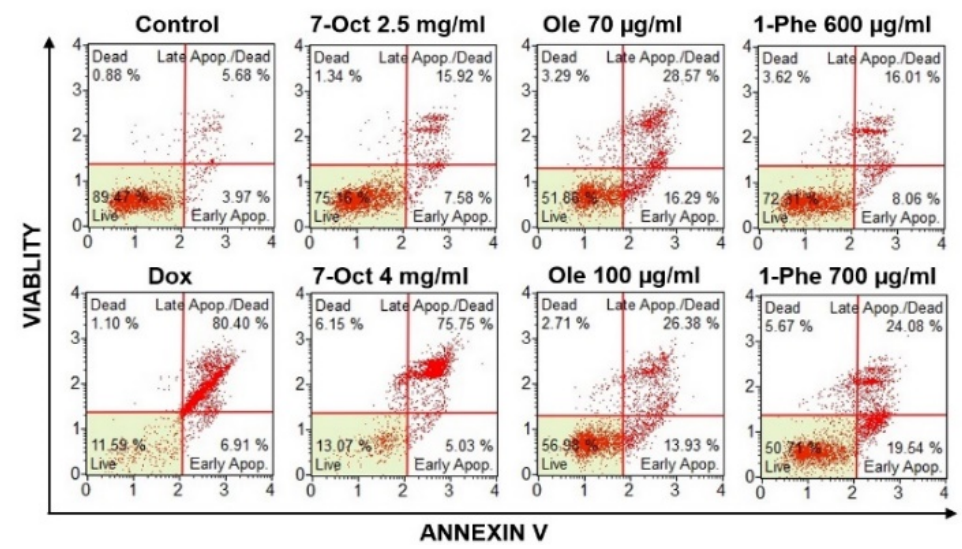

(B)

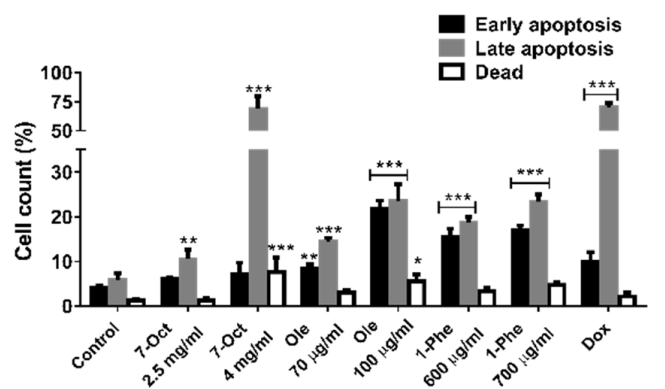

(C)

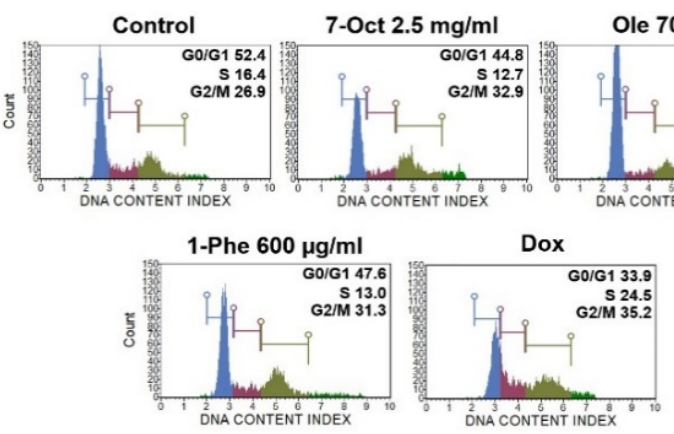

(E)

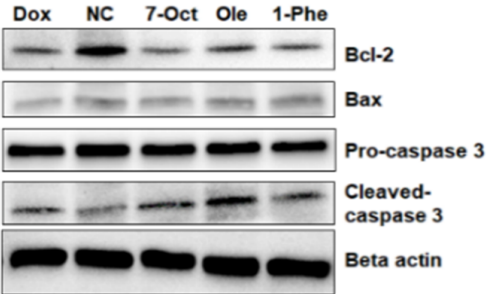

(D)

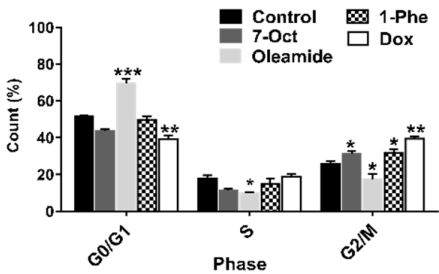

(F)

Figure 5. 7-octenoic acid (7-Oct), oleamide (Ole), and 1-phenyl-2-pentanol (1-Phe) induced apoptosis and cell cycle arrest in MDA-MB-231 cells. (A) Hoechst 33258 staining. (B,C) Apoptosis analysis using AnnexinV/7-AAD staining. (D) Western blot analysis. (E,F) Cycle cell progression. Cells were incubated with 7-octenoic acid $(2.5 \mathrm{mg} / \mathrm{mL})$, oleamide $(70 \mu \mathrm{g} / \mathrm{mL}), 1$-phenyl-2-pentanol $(600 \mu \mathrm{g} / \mathrm{mL})$, or doxorubicin (Dox; $1.5 \mu \mathrm{M}$ ) for $24 \mathrm{~h}$ in all experiments. Data represent the mean \pm SEM of three independent experiments. $\left({ }^{*} p<0.05,{ }^{* *} p<0.01,{ }^{* * *} p<0.001\right)$. 7-Oct, 7-octenoic acid; 1-Phe, 1-Phenyl-2-pentanol; Ole, oleamide; dox, doxorubicin. 


\subsection{Bioactive Compounds Suppressed MDA-MB-231 Cell Migration and Induced Apoptosis in Different Cancer Cell Lines}

TNBC is an aggressive form of breast cancer with high metastasis. We determined the effects of the compounds on MDA-MB-231 cell migration using the in vitro scratch assay (Figure 6A,B). The number of migratory cells across the wound regions was significantly decreased after treatment with 7-octenoic acid, oleamide, and 1-phenyl-2-pentanol. This result indicated that 7-octenoic acid, oleamide, and 1-phenyl-2-pentanol may have the ability to inhibit MDA-MB-231 cell migration. As oleamide exhibited notable anticancer effects against MDA-MB-231, we further investigated the effect of oleamide on two different cancer cell lines, including human myelogenous leukemia cell K562 and human squamous cell carcinoma lines SCC-15. Result revealed that treatment with 70 and $100 \mu \mathrm{g} / \mathrm{mL}$ of oleamide increased late apoptosis in both K562 (13.76\% and 87.11\%) and SCC-15 (11.37\% and $24.47 \%$ ) when compared to the control (Figure 6C). Additionally, cell cycle analysis indicated that oleamide induced cell cycle arrest at G0/G1 phase in both K562 (36.8 to 54.7\%) and SCC-15 (47.9 to 51.5\%) when compared to the control (Figure 6D). The results suggested that oleamide has potential as an anticancer treatment for MDA-MB-231 TNBC and other cell lines.

\subsection{Preliminary Prediction of Compound-Targets Interactions with Drug Target Commons}

Understanding the binding target of compounds provides important insights into the therapeutic approach. In this study, we preliminary predicted the blinding target of oleamide based on similarity-based approaches and then query the target profiles in drug target commons platform (Table 2) [34]. We found 16 target molecules, including four transmembrane receptors, nine enzymes, and three nuclear proteins. However, the prediction of certain blinding-targets required the combinations of data from multiple platforms such as DrugBank, BindingDB, and Protein Data Bank.

Table 2. Prediction of oleamide blinding-targets with drug target commons.

\begin{tabular}{|c|c|c|c|}
\hline Target Preferred Name & Gene Names & Target Class & References \\
\hline 1. GABA-A receptor $\beta 3$ subunit & GABRB3 & Ion channel & {$[35,36]$} \\
\hline 2. Cannabinoid receptor 1 (CB1) & CNR1 & GPCR & [36] \\
\hline 3. $5-\mathrm{HT}_{2 \mathrm{~A}}$ receptor & HTR2A & GPCR & {$[37,38]$} \\
\hline 4. $\mathrm{P} 2 \mathrm{Y}$ receptors & $P 2 R Y$ & GPCR & [39] \\
\hline 5. Fatty acid amide hydrolase & $F A A H$ & Enzyme & [40-42] \\
\hline 6. Acyl coenzyme A: cholesterol acyltransferase 1 & Soat1 & Enzyme & {$[43]$} \\
\hline 7. Cytochrome p450 2c19 & Cyp2c19 & Enzyme & Pubchem bioassay \\
\hline 8. Cytochrome p450 2c19 & Cyp2c19 & Enzyme & Pubchem bioassay \\
\hline 9. Cytochrome P450 2C9 & Cyp2c9 & Enzyme & Pubchem bioassay \\
\hline 10. Cytochrome P450 2D6 & Cyp2d6 & Enzyme & Pubchem bioassay \\
\hline 11. Cytochrome P450 3A4 & Cyp3a4 & Enzyme & Pubchem bioassay \\
\hline 12. Cytochrome p450 1a2 & Cyp1a2 & Enzyme & Pubchem bioassay \\
\hline 13. Ubiquitin carboxyl-terminal hydrolase 1 & Usp1 & Kinase & Pubchem bioassay \\
\hline 14. NF-kappa-B, p105 subunit & $N f k b 1$ & Nuclear receptor & Pubchem bioassay \\
\hline 15. Proto-oncogene c-jun & Jun & Nuclear receptor & Pubchem bioassay \\
\hline 16. Cellular tumor antigen $\mathrm{p} 53$ & Tp53 & Nuclear receptor & Pubchem bioassay \\
\hline
\end{tabular}




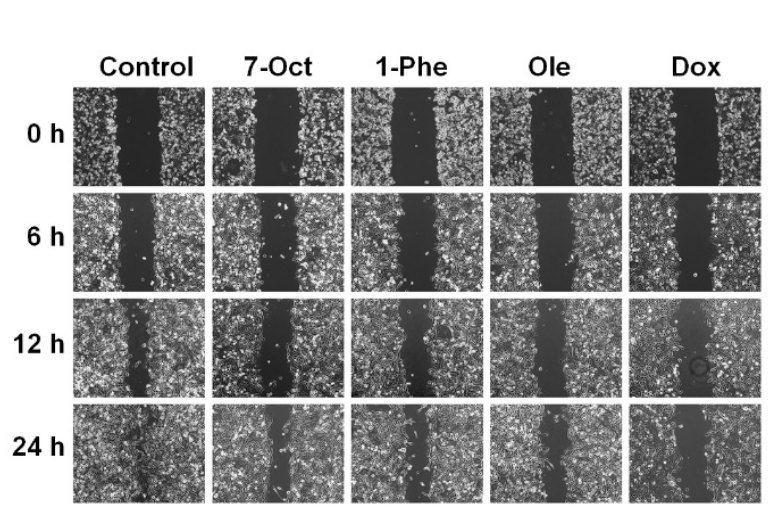

(A)

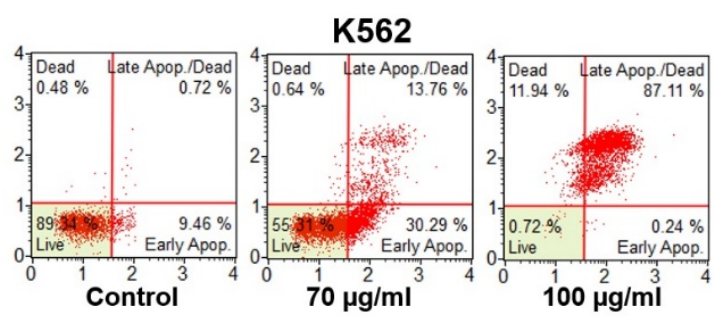

SCC-15

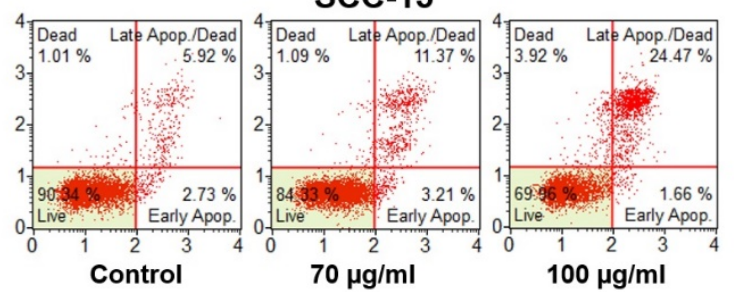

(C)
- Control

$\square$ 7-Oct $1.5 \mathrm{mg} / \mathrm{m}$

$\square$ Ole $40 \mu \mathrm{g} / \mathrm{ml}$

1-Phe $250 \mu \mathrm{g} / \mathrm{m}$

Dox $1.5 \mu \mathrm{M}$

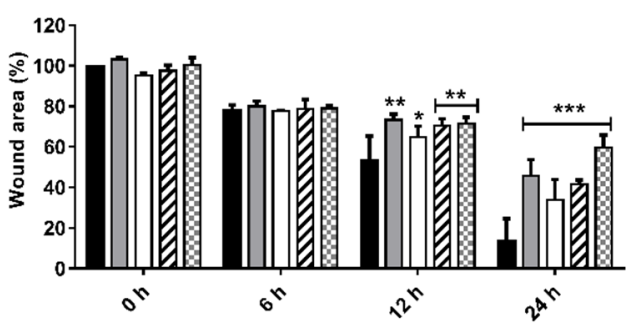

(B)

\section{K562}

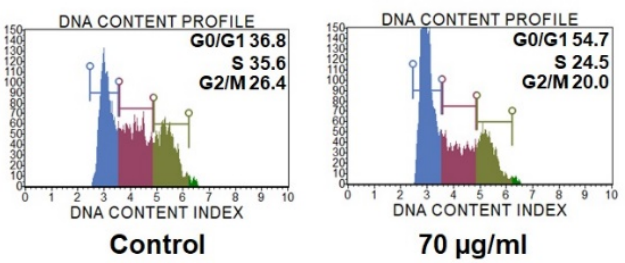

SCC -15

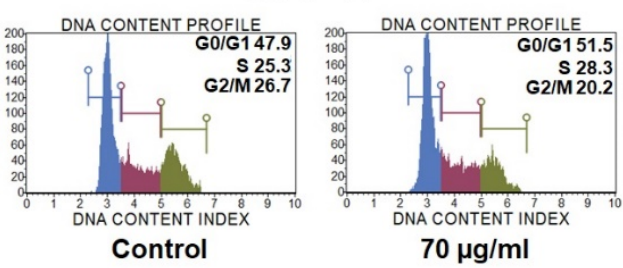

(D)

Figure 6. Effect of 7-octenoic acid, oleamide, and 1-phenyl-2-pentanol in vitro cell migration. (A) MDA-MB-231 cells were scratch wounded and incubated with compounds, doxorubicin, or complete medium (control). The wound areas were imaged at $0,6,12$, and $24 \mathrm{~h}$ post-scratching. (B) Wound area (\%) summarized from triplicate data. One-way ANOVA test was performed with multiple comparison corrections (Dunnett test). Data represent the mean \pm SEM of three independent experiments. $\left({ }^{*} p<0.05\right.$, ** $p<0.01,{ }^{* * *} p<0.001$ ). (C) Apoptosis and (D) cell cycle analysis by Muse cell analyzer. Cells were treatment with compounds for $24 \mathrm{~h}$ in all experiments. 7-Oct, 7-octenoic acid; 1-Phe, 1-Phenyl-2-pentanol; Ole, oleamide; dox, doxorubicin.

\section{Discussion}

MO is a widely consumed traditional plant in many Asian and South East Asian countries. MO possesses many bioactive compounds with potential health benefits including anti-inflammatory, antioxidant, and anticancer properties [10]. Although much research supports the anticancer effect of MOL, the actual bioactive compounds responsible have not been well characterized. In this study, we explored the anticancer effect, conducted bioassay-guided fractionation, and identified bioactive compounds from MOL extract against the MDA-MB-231 TNBC cell line. We demonstrated that MOL crude EtOAc extract showed the greatest anticancer activity but was non-toxic to primary human macrophage cells (Figure S7). Crude EtOAc extract and its derived fractions were screened for in vitro anticancer activities. Fraction no. 7 was subjected for re-fractionation and finally, 
the 10 candidate compounds were tentatively identified from the active sub-fraction no. 7.7 using LC-ESI-QTOF-MS. Moreover, we explored the biological activity of three compounds, including 7-octenoic acid, 1-phenyl-2-pentanol, and oleamide against MDA-MB-231, SCC-15, and K562 cell lines.

Previous studies indicated that the tumor suppressor $p 53$ gene plays an important role in response to DNA damage and other genomic instability. Activation of p53 is crucial in inducing a p53-dependent pathway leading to cell cycle arrest or apoptosis [44]. The up-regulation in $p 53$ gene expression following MOL fraction no. 7 treatment may explain the cell cycle arrest and apoptosis caused by this fraction (Figure 3). Caspase-3 is a protein that is cleaved and thus activated upon the initiation of apoptosis. Cleaved caspase-3 propagates the apoptotic signal by cleaving downstream executioner caspases at their intersubunit linker [45]. We found that fraction no. 7 treatment of MDA-MB-231 cells resulted in concentration-dependent activation of caspase-3 (Figure 3). The Bcl-2 family of proteins are the central regulators of the mitochondrial cell-intrinsic apoptosis [46]. In contrast, an increase in expression of Bax induces cell death and leads to the elimination of tumor cells $[46,47]$. Therefore, we measured the expression of Bcl-2 family proteins, and we found that fraction no. 7 treatment resulted in increased expression of Bax and decreased expression of Bcl-2. Collectively, our results reveal that MOL fraction no. 7 up-regulates pro-apoptotic p53, cleaved caspase-3, and Bax, while down-regulating anti-apoptotic Bcl-2 protein levels.

On the other hand, flow cytometry analysis with annexin V and PI staining indicated that MOL fraction no. 7 was not only able to induce apoptosis but also triggered necrotic cell death in MDA-MB-231 cells. This mechanism might be caused by the activation of caspase- 3 which triggers cross-talk to necrotic signaling, resulting in secondary necrosis $[48,49]$. The main features of secondary necrosis are osmotic cell swelling and lysis that lead to leakage of the cell contents; thereby it may cause tissue injury and induction of inflammation and other immune responses if the dying cells are not quickly removed by phagocytes [48,49]. MOL fraction no. 7 induced MDA-MB-231 cell cycle arrest at G2/M phase similar to the study of Al-Asmari et al., that found increased MDA-MB-231 cell accumulation in the G2/M phase after treatment with crude EtOAc extract [50].

Previously, MOL has been described as containing many phenolic compounds that exert anticancer effects including quercetin, kaempferol, isothiocyanate, and gallic acid [12,51]. Moreover, long-chain fatty acids and their derivatives are also considered as anticancer compounds. In this study, based on bioassay-guided fractionation and LC-ESI-QTOF-MS analysis, we identified 10 candidate anticancer compounds (Table 1), including two aromatic compounds (C1 and C3), five fatty acids (C2, C5-C8), two fatty amides (C9 and C10) and a lactone compound (C4). Octadecadienoic acid and oleamide have been previously described in MOL extracts [52-54] as seen here. Based on commercially available compounds, we selected three candidate compounds (oleamide, 7-octenoic acid, and 1-phenyl-2-pentanol) to explore cytotoxicity against MDA-MB-231 cells. Oleamide, also known as oleyl amide or 9-octadecenamide, belongs to the class of fatty amides. These are carboxylic acid amide derivatives of fatty acids, that are formed from a fatty acid and an amine. Oleamide was discovered in the cerebrospinal fluid of sleep-deprived cats [55]. It has been observed that oleamide possesses several biological activities especially sleep induction [56] and immunological suppression [57]. Moreover, oleamide has been reported to inhibit gap junction communication on human breast cancer MDA-MB-231 cells [58,59]. It has been reported that 9-octadecenoic acid found about $20.89 \%$ in MOL [60]. 7-octenoic acid is a long-chain fatty acid and 1-phenyl-2-pentanol is used as a flavoring agent. There biological activity has not been reported before. In the present study, we demonstrate the anticancer activity of these compounds against breast cancer cells; we found that oleamide exhibits the strongest anticancer activity when compared to the other two compounds. However, of 1-phenyl-2-pentanol and 7-octadecenoic acid may act in combination or synergistically with other compounds to enhance their activity. We present preliminary results of the synergistic effect of identified compounds (Figure S8) after incubation for $24 \mathrm{~h}$. This requires further investigation. Our research provides ten candidate bioactive compounds that might be useful for investigating for anti-cancer activity and future development of treatments for TNBC and other type of 
cancer. Although we identified the potential compounds by studying their mechanisms of actions, their interaction or combination effect remains unclear. Several previous studies demonstrated that combination therapy can improve the efficacy of the drug in TNBC cell lines [61-63]. For example, combination treatment of selumetinib (MEK1/2 inhibitor) with buparlisib (PI3K inhibitor) is synergistic in MDA-MB-231 cells [61]. Therefore, the future investigation of anticancer drugs and active natural product combination with chemotherapy, radiotherapy, and other treatments is important. Additionally, the limitation of this study is performed only MDA-MB-231, TNBC model. It is unclear whether these compounds still show the same efficacy as other TNBC cell lines. Thus, further study should be performed in other TNBC cell lines such as MDA-MB-175, MDA-MB-435, and MDA-MB-436 [64]. However, this study demonstrated that the anticancer efficacy of oleamide with other cancer cell lines, including human myelogenous leukemia cell K562 and human squamous cell carcinoma lines SCC-15, which revealed that oleamide has potential anticancer activity for other cancer types. Recently, patient-derived cancer models have been proposed to gradually replace the cancer cell lines for translational research [65-67]. For example, lung cancer patients derived samples were studied the effective drug combination responds [65]. T-cell prolymphocytic leukemia-derived model were successfully used for identification and prediction of drug combination treatment [67]. In the present study, we demonstrate the bioassay-guided fractionation and identification of the potential anticancer compounds from MOL extract against TNBC cell lines MDA-MB-231. There are 10 compounds were tentatively identified by LC-ESI-QTOF-MS analysis. Moreover, also demonstrates the anticancer properties of compounds no. 2 (7-octenoic acid), no. 3 (1-phenyl-2-pentanol), and no. 9 (oleamide) against MDA-MB-231 cell and other cancer lines including SCC-15 and K562. Therefore, further investigation of MOL extract and bioactive compounds on TNBC patient derived samples and patient-derived xenograft models are powerful tool for combination effects and to overcome the resistance mechanisms.

\section{Materials and Methods}

\subsection{Cell Culture and Chemicals}

MDA-MB-231, SCC15, and K562 were obtained from American Type Cell Collection (Manassas, VA, USA). They were cultured in Dulbecco's modified eagle medium (Gibco, Carlsbad, CA, USA), DMEM/F12 (Gibco, Carlsbad, CA, USA) and RPMI 1640 (Gibco, Carlsbad, CA, USA), respectively. Medium cultured were supplemented with 10\% fetal bovine serum (Gibco, Carlsbad, CA, USA) and 1\% penicillin/streptomycin (Gibco, Carlsbad, CA, USA). Cells were cultured in a humidified atmosphere with $5 \% \mathrm{CO}_{2}$ at $37^{\circ} \mathrm{C}$. Primary antibodies against $\beta$-actin, Bax, Bcl-2, caspase-3 were from Santa Cruz (Santa Cruz, CA, USA), and anti-cleaved caspase-3 was from Affinity Biosciences (Cincinnati, OH, USA). Mouse anti-human IgG1 Fc secondary antibody conjugated with horseradish peroxidase (HRP) and 3-(4,5-Dimethylthiazol-2-yl)-2,5-Diphenyltetrazolium Bromide (MTT) were from Thermo Fischer Scientific (Waltham, MA, USA). Oleamide, 7-octenoic acid, and 1-phenyl-2-entanol were from Sigma Aldrich (St. Louis, MO, USA).

\subsection{Extraction and Fractionation of MOL Extract}

MOL dried powder (COA lot no. 5534) from Khaolaor Laboratories Co., Ltd. (Samutprakan, Thailand) was subjected to serial exhaustive extraction. One kilogram of MOL powder was sequentially extracted using hexane, ethyl acetate (EtOAc), and 95\% ethanol (EtOH) as extractants. The extraction process was repeated three times with $1 \mathrm{~L}$ of each solvent at room temperature (RT). The extracts were filtered through Whatman no. 3 filter paper and the filtrates were concentrated using a rotary evaporator (Heidolph Hei-VAP Value HB/G3B) to produce hexane extract (35.37 g), EtOAc extract (44.78 g), and EtOH extract $(66.63 \mathrm{~g})$. The crude EtOAc extract $(10 \mathrm{~g})$ was dissolved in hexane-EtOAc $(70-30 \%)$ and separated by chromatography on a silica gel column; a gradient sequentially formed of hexane-EtOAc (90-10\%, 80-20\%, 70-30\%, 60-40\%, 50-50\%, 40-60\%, 30-70\%, 20-80\%, 10-90\%, and 100\% EtOAc), 
and EtOAc-methanol $(\mathrm{MeOH})(90-10 \%, 80-20 \%$, and $100 \% \mathrm{MeOH})$ were used as the mobile phase for elution. All collected fractions were monitored and combined based on the thin layer chromatography (TLC) pattern. Next, the active fraction (fraction no. 7; $135 \mathrm{mg}$ ) was dissolved in hexane-EtOAc $(30-70 \%)$ and re-fractionated by silica gel column chromatography; a gradient sequentially formed of hexane-EtOAc (90-10\%, 80-20\%, 70-30\%, 50-50\%, and 100\% EtOAc), and EtOAc-MeOH (90-10\%) were used as the mobile phase for elution. All sub-fractions (nos. 7.1-7.8) were tested for anticancer activity using the MTT assay. The strongest active sub-fraction (sub-fraction no. 7.7) was then subjected to the identification of bioactive compounds using at-line-LC-ESI-QTOF-MS/MS analysis. All extracts were stored at $-20^{\circ} \mathrm{C}$ until use.

\subsection{At-Line-LC-ESI-QTOF-MS/MS Analysis}

The active subfraction of MOL extract $(20 \mathrm{mg} / \mathrm{mL})$ was prepared and injected into an Agilent 1260 Infinity Series HPLC system (Agilent Technologies Inc., Waldbronn, Germany) coupled to an Agilent 6540 QTOF-MS spectrometer (Agilent Technologies, Inc., Singapore) with an electrospray ionization (ESI) source. For HPLC separation, a mobile phase of $0.1 \%$ formic acid in water $(v / v)(A)$ and $0.1 \%$ formic acid in acetonitrile ( $v / v$ ) (B) was used with gradient elution from $20 \% \mathrm{~B}$ to $90 \% \mathrm{~B}$ in $30 \mathrm{~min}$, hold on $3 \mathrm{~min}$ and post-run for $5 \mathrm{~min}$. The sample separation was performed on a Luna C18 (2) $100^{\circ} \mathrm{A}$, $4.6 \times 150 \mathrm{~mm}, 5 \mu \mathrm{m}$ column (serial no. 728946-40; Phenomenex, CA, USA) at a flow rate of $0.5 \mathrm{~mL} / \mathrm{min}$, with the column temperature set at $35{ }^{\circ} \mathrm{C}$. The eluent was split into two flows using a 9:1 ratio. The major part was collected in a 96-well plate with $30 \mathrm{~s}$ per well, while the minor part flowed to an ESI-QTOF-MS system. The operating parameters for MS detection were as follows: drying gas $\left(\mathrm{N}_{2}\right)$ flow rate $10.0 \mathrm{~L} / \mathrm{min}$; drying gas temperature $350{ }^{\circ} \mathrm{C}$; nebulizer pressure 30 psig; capillary $3500 \mathrm{~V}$; skimmer $65 \mathrm{~V}$; octapole RFV $750 \mathrm{~V}$; and fragmentor voltage $100 \mathrm{~V}$ in positive mode. The mass range was set at m/z 100-1200 amu with a $250 \mathrm{~ms} / \mathrm{spectrum}$. The mass fragmentation was operated on auto $\mathrm{ms} / \mathrm{ms}$ mode with three collision energies of 10, 20, and $40 \mathrm{eV}$, respectively. All acquisition and analysis of data were controlled by Agilent MassHunter Data Acquisition Software B.05.01 and Agilent MassHunter Qualitative Analysis Software B.06.0, respectively. The micro-fractions in a 96-well plate were dried using a sample concentrator (Techne, Staffordshire, UK) and kept at $-20^{\circ} \mathrm{C}$ before being tested.

\subsection{Identification of Active Compounds}

The samples from the 96 well plate that showed bioactivity were linked to the LC-ESI-QTOF-MS/MS chromatogram by time. The active compounds with MS and MS/MS data were tentatively identified: the mass data were compared with previous reports and using public databases ((the Human Metabolomics Database; http://www.hmdb.ca; accessed on 30 December 2019), Chemspider (http:// www.chemspider.com; accessed on 30 December 2019), and Metlin database (https://metlin.scripps.edu; accessed on 30 December 2019)).

\subsection{Cell Viability Assay}

The cytotoxicity of the MOL extract and its derived fractions were determined using the methyl thiazol tetrazolium (MTT) assay. MDA-MB-231 cells were seeded into 96-well plates at a density of $1 \times 10^{4}$ cells/well and treated with MOL extract at concentration 75, 100, and $150 \mu \mathrm{g} / \mathrm{mL}$ for $24 \mathrm{~h}$. MTT salt solution was added and the plate was incubated for $3 \mathrm{~h}$ at $37^{\circ} \mathrm{C}$. Then, formazan crystals were dissolved in $100 \mu \mathrm{l}$ DMSO. The absorbance was measured at $570 \mathrm{~nm}$ using an ELISA plate reader (PerkinElmer, Inc., Waltham, MA, USA).

\subsection{Colony Formation Assay}

MDA-MB-231 cells were seeded into 6-well plates at a density of 500 cells/well and incubated for $24 \mathrm{~h}$. Cells were treated with MOL extract or its derived fractions for $24 \mathrm{~h}$ and the plates were then cultured for 14 days in complete DMEM. After 14 days, cells were fixed with $10 \%$ neutral formalin and stained with $0.5 \%$ crystal violet to visualize colonies and photographed. 


\subsection{Apoptosis and Cell Cycle Analysis}

Cell apoptosis and cell cycle analysis were examined on the Muse Cell Analyzer (EMD Millipore, Billerica, MA, USA). MDA-MB-231 cells were plated into 24 -well plates at the density of $5 \times 10^{4}$ cells $/$ well. Cells were incubated with MOL extract $(150 \mu \mathrm{g} / \mathrm{mL})$, fractions no. 1-11 $(150 \mu \mathrm{g} / \mathrm{mL})$, 7-octenoic acid $(2.5$ and $4 \mathrm{mg} / \mathrm{mL})$, oleamide (70 and $100 \mu \mathrm{g} / \mathrm{mL})$, 1-phenyl-2-pentanol $(600$ and $700 \mu \mathrm{g} / \mathrm{mL})$, or doxorubicin $(1.5 \mu \mathrm{M})$ for $24 \mathrm{~h}$. Cell apoptosis was examined by staining with Muse ${ }^{\mathrm{TM}}$ Annexin V and Dead Cell reagent (EMD Millipore, Billerica, MA, USA; cat. no. MCH100105). For cell cycle analysis, cells were fixed in chilled $75 \%$ ethanol for $3 \mathrm{~h}$ at $-20^{\circ} \mathrm{C}$. Then cells were washed with PBS and incubated with Muse ${ }^{\mathrm{TM}}$ Cell Cycle Reagent (Millipore, Billerica, MA, USA; cat. no. MCH100106) for $30 \mathrm{~min}$ in the dark at RT. Cells were read on the Muse cell analyser.

\subsection{Cell Migration Assay}

Migration of MDA-MB-231 cells was examined by using the in vitro scratch assay. MAD-MB-231 cells $\left(1 \times 10^{6}\right)$ were plated into 6-well plates and cultured for $24 \mathrm{~h}$ to form monolayers. The wound area was created by scratching with a SPLScar ${ }^{\mathrm{TM}}$ Scratcher. Cells were then incubated with 7-octenoic acid $(1.5 \mathrm{mg} / \mathrm{mL})$, oleamide $(40 \mu \mathrm{g} / \mathrm{mL})$, 1-Phenyl-2-pentanol $(250 \mu \mathrm{g} / \mathrm{mL})$, doxorubicin $(1.5 \mu \mathrm{M})$, or media alone for $24 \mathrm{~h}$. The images were captured at $0,6,12$, and $24 \mathrm{~h}$ using an inverted microscope (Zeiss Microscopy, Oberkochen, Germany). The percentage of wound closure was calculated using ImageJ software (Version 1.52a, Madison, WI, USA).

\subsection{Hoechst Staining}

To assess the effects of compounds on nuclear material, MDA-MB-231 cells were stained with Hoechst 33342. MDA-MB-231 cells were seeded at a density of $7 \times 10^{5}$ cells/well in a 6-well plate containing glass cover slips. Cells were treated with 7 -octenoic acid $(2.5 \mathrm{mg} / \mathrm{mL})$, oleamide $(70 \mu \mathrm{g} / \mathrm{mL})$, and 1-phenyl-2-pentanol $(600 \mu \mathrm{g} / \mathrm{mL})$ for $24 \mathrm{~h}$. After incubation, cells were washed with PBS, fixed with

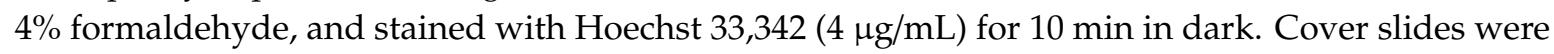
then mounted with $70 \%$ glycerol and images were captured with an inverted microscope using $350 \mathrm{~nm}$ excitation and $450 \mathrm{~nm}$ emission filters (Zeiss Microscopy, Oberkochen, Germany). A total of three images per treatment were captured at $40 \times$ magnification.

\subsection{Reverse Transcription Quantitative Real-Time PCR (RT-qPCR)}

MDA-MB-231 cells $\left(1 \times 10^{5}\right)$ were plated into a 12-well culture plate. Cells were then treated with fraction no. 7 (75 and $100 \mu \mathrm{g} / \mathrm{mL}$ ) for $24 \mathrm{~h}$. For control, cells were incubated with culture medium alone. The total RNA was isolated by using Trizol reagent (Invitrogen, Carlsbad, CA, USA) according to the manufacturer's instructions. First-strand cDNA was synthesized using Tetro cDNA Synthesis Kit (BIOLINE USA Inc, Taunton, MA, USA). The resulting cDNAs were amplified with different primers (Supplement Table S1) using the SensiFAST ${ }^{\mathrm{TM}}$ SYBR ${ }^{\circledR}$ No-ROX Kit (BIOLINE USA Inc., Taunton, MA, USA). Relative differences in gene expression among groups were determined from the quantification cycle $(\mathrm{Cq})$ values. These values were first normalized to a housekeeping gene ( $\beta$-actin) in the same sample $(\Delta \mathrm{Cq})$ and are expressed as the fold-change over control $\left(2^{-\Delta \Delta \mathrm{Cq}}\right)$. Real-time fluorescence detection was performed using a CFX96 Touch Real-Time PCR Detection System (Bio-Rad, Hercules, CA, USA).

\subsection{Western Blot Analysis}

MDA-MB-231 cells $\left(7 \times 10^{5}\right)$ were plated into 6-well culture plates. Cells were incubated with fraction no. 7 (75 and $100 \mu \mathrm{g} / \mathrm{mL}), 7$-octenoic acid $(2.5$ and $4 \mathrm{mg} / \mathrm{mL})$, oleamide $(70$ and $100 \mu \mathrm{g} / \mathrm{mL}$ ), 1-phenyl-2-pentanol (600 and $700 \mu \mathrm{g} / \mathrm{mL})$, or doxorubicin $(1.5 \mu \mathrm{M})$ for $24 \mathrm{~h}$. Cells were lysed in RIPA buffer (Bio Basic Inc.) supplemented with Protease/Phosphatase Inhibitor Cocktail (Sigma Aldrich, St. Louis, MO, USA) for $30 \mathrm{~min}$ and then centrifuged at $14,000 \times \mathrm{g}$ for $15 \mathrm{~min}$ at $4 \mathrm{C}$. Protein concentration 
was determined by the Bradford assay. Equal amounts of protein samples were heated, separated in $12 \%$ SDS-PAGE $(150 \mathrm{~V}, 1 \mathrm{~h})$, and transferred onto nitrocellulose membranes (100 V, $1.30 \mathrm{~h})$. The membranes were washed and blocked with $2 \%$ BSA in Tris-buffered saline containing $0.5 \%$ Tween 20 (TBST) for $1 \mathrm{~h}$ at RT. Then the membranes were probed with primary antibodies against $\beta$-actin, Bax, Bcl-2, caspase-3, or cleaved caspase- 3 by incubating overnight at $4{ }^{\circ} \mathrm{C}$. The membranes were then washed three-time with TBST and incubated with secondary antibodies for $1 \mathrm{~h}$ at RT. Protein detection was performed by adding horseradish peroxidase chemiluminescence substrate. The intensity of each band was analyzed using Image Lab Software (Version 5.1, Hercules, CA, USA).

\subsection{Statistical Analysis}

Data are shown as mean \pm standard error (SEM) of three independent experiments. For comparisons of more than two groups one-way ANOVA were performed with multiple comparison correction (Dunnett test) using GraphPad Prism 6.0 software. $p$-values $<0.05$ were considered statistically significant.

\section{Conclusions}

We demonstrate the bioassay-guided fractionation and identification of the potential anticancer compounds from MOL extract against TNBC cell lines MDA-MB-231. Crude EtOAc extract and their fractions were screened for anticancer activity using different bioassay. We tentatively identified 10 compounds from sub-fraction no 7.7 by LC-ESI-QTOF-MS. Moreover, we also investigate the individual mechanisms of actions of three identified compounds, including 7-octenoic acid, oleamide, and 1-phenyl-2-pentanol against TNBC cell lines (Figure 7). Our findings suggest that oleamide has strongest potential as an anticancer treatment by induce apoptosis through suppress Bcl-2 expression and subsequently promote activation of caspase 3. This is the first report concerning MOL extract and oleamide activity against MDA-MB-231 cell line.

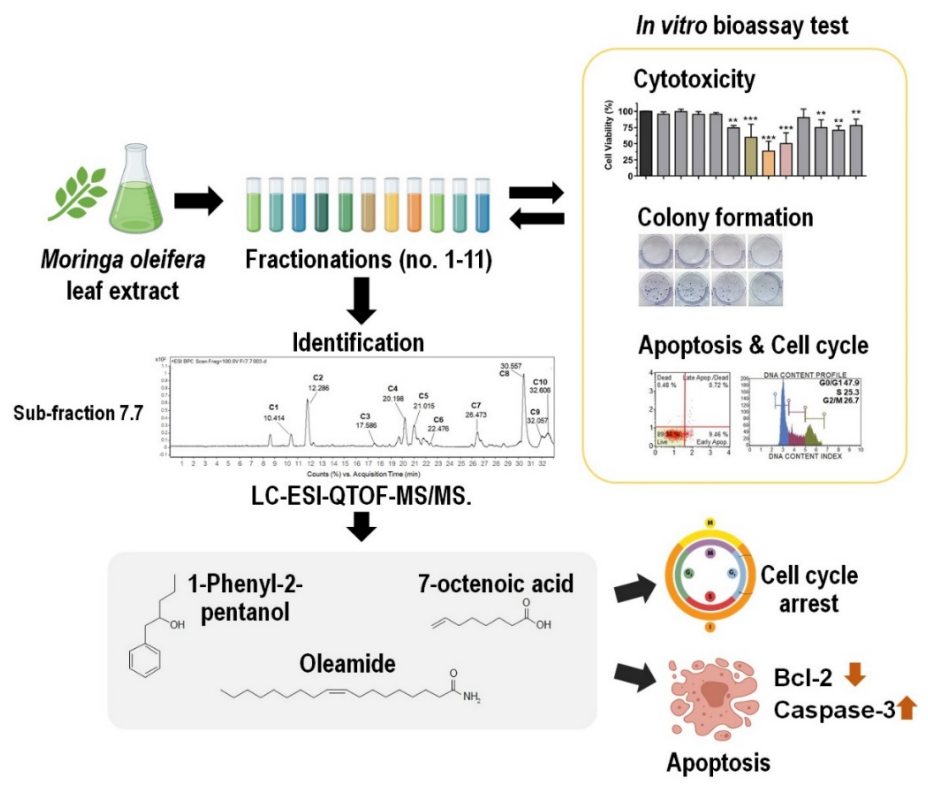

Figure 7. Bioassay-guided fractionation and identification of potential anticancer compounds from MOL extract against TNBC cell lines MDA-MB-231. Crude EtOAc extract was fractionated (no.1-11) and screened for anticancer activities with different in vitro bioassay tests. The strongest fraction was selected for sub-fractionation and identification of bioactive compounds using LC-ESI-QTOF-MS/MS. Three candidate compounds (1-phenyl-2-pentanol, oleamide, and 7-octenoic acid) exhibited anticancer effects through inducing cell cycle arrest. Additionally, suppression of Bcl-2 resulting in the disruption of mitochondrial membrane permeability and subsequent release of apoptogenic factors such as cytochrome $c$, which activates caspase 3 and finally causes cell apoptosis ${ }^{* *} p<0.01,{ }^{* * *} p<0.001$ ). 
Supplementary Materials: The following are available online at http://www.mdpi.com/1424-8247/13/12/464/s1, Figure S1: Colony formation assay, Figure S2: Induction of apoptosis in MDA-MB-231 cells, Figure S3: Effect of MOL extract and its derived fractions on the distribution of MDA-MB-231 cells in the cell cycle, Figure S4: Cell viability of MDA-MB-231 cells after treatment with sub-fractions no.7.1-7.8, Figure S5: Overlays of LC-MS chromatograms of MO sub-fraction no.7.7 with active compounds no.1-10. Figure S6: Cytotoxicity of identified compounds on MDA-MB-231 cells, Figure S7: Cell viability of primary human macrophage after treatment with crude EtOAc extract, Figure S8: Combination effect of compounds on MDA-MB-231 cell viability, Figure S9: Original Images of Blots and Gels, Table S1: Primer sequences used in RT-qPCR assay.

Author Contributions: The authors declare no conflict of interest. Conceptualization: P.W., P.P., N.S., and K.U.; methodology: P.W. and N.S.; software: N.N.; formal analysis: P.W.; investigation: P.W.; writing-original draft preparation: P.W.; writing-review and editing: K.U. and P.C.C.; funding acquisition: K.U. All authors have read and agreed to the published version of the manuscript.

Funding: This research was funded by the Royal Golden Jubilee Ph.D. Program (grant no. PHD/0002/2559), Thailand Science Research and Innovation, and Naresuan University (grant no. R2564B002).

Acknowledgments: We would like to thank staff of Blood Bank Unit of Naresuan University Hospital, Thailand for providing blood samples. We also thank Khaolaor Laboratories Co., Ltd., Samutprakan, Thailand for providing Moringa oleifera dried powder.

Conflicts of Interest: The authors declare no conflict of interest.

\section{References}

1. American Cancer Society. Breast Cancer Facts E Figures 2017-2018; American Cancer Society: Atlanta, GA, USA, 2017.

2. American Cancer Society. Cancer Facts E Figures 2018; American Cancer Society: Atlanta, GA, USA, 2018.

3. Kumar, P.; Aggarwal, R. An overview of triple-negative breast cancer. Arch. Gynecol. Obstet. 2016, 293, 247-269. [CrossRef]

4. Foulkes, W.D.; Smith, I.E.; Reis-Filho, J.S. Triple-negative breast cancer. N. Engl. J. Med. 2010, 363, 1938-1948. [CrossRef]

5. Andre, F.; Zielinski, C.C. Optimal strategies for the treatment of metastatic triple-negative breast cancer with currently approved agents. Ann. Oncol. Off. J. Eur. Soc. Med Oncol. 2012, 23 (Suppl. 6), vi46-vi51. [CrossRef]

6. Odle, T.G. Adverse effects of breast cancer treatment. Radiol. Technol. 2014, 85, 297M-323M.

7. Thurber, M.D.; Fahey, J.W. Adoption of Moringa oleifera to combat under-nutrition viewed through the lens of the "Diffusion of innovations" theory. Ecol. Food Nutr. 2009, 48, 212-225. [CrossRef]

8. Saini, R.K.; Sivanesan, I.; Keum, Y.S. Phytochemicals of Moringa oleifera: A review of their nutritional, therapeutic and industrial significance. 3 Biotech 2016, 6, 203. [CrossRef]

9. Dholvitayakhun, A.; Cushnie, T.P.; Trachoo, N. Antibacterial activity of three medicinal Thai plants against Campylobacter jejuni and other foodborne pathogens. Nat. Prod. Res. 2012, 26, 356-363. [CrossRef]

10. Leone, A.; Spada, A.; Battezzati, A.; Schiraldi, A.; Aristil, J.; Bertoli, S. Cultivation, Genetic, Ethnopharmacology, Phytochemistry and Pharmacology of Moringa oleifera Leaves: An Overview. Int. J. Mol. Sci. 2015, 16, 12791-12835. [CrossRef]

11. Baldisserotto, A.; Buso, P.; Radice, M.; Dissette, V.; Lampronti, I. Moringa oleifera Leaf Extracts as Multifunctional Ingredients for "Natural and Organic" Sunscreens and Photoprotective Preparations. Molecules 2018, 23, 664. [CrossRef]

12. Paikra, B.K.; Dhongade, H.K.J.; Gidwani, B. Phytochemistry and Pharmacology of Moringa oleifera Lam. J. Pharmacopunct. 2017, 20, 194-200. [CrossRef]

13. Panda, S.; Kar, A.; Sharma, P.; Sharma, A. Cardioprotective potential of N,alpha-L-rhamnopyranosyl vincosamide, an indole alkaloid, isolated from the leaves of Moringa oleifera in isoproterenol induced cardiotoxic rats: In vivo and in vitro studies. Bioorganic Med. Chem. Lett. 2013, 23, 959-962. [CrossRef]

14. Ghasi, S.; Nwobodo, E.; Ofili, J.O. Hypocholesterolemic effects of crude extract of leaf of Moringa oleifera Lam in high-fat diet fed wistar rats. J. Ethnopharmacol. 2000, 69, 21-25. [CrossRef]

15. Ganguly, R.; Guha, D. Alteration of brain monoamines \& EEG wave pattern in rat model of Alzheimer's disease \& protection by Moringa oleifera. Indian J. Med. Res. 2008, 128, 744-751.

16. Cheenpracha, S.; Park, E.J.; Yoshida, W.Y.; Barit, C.; Wall, M.; Pezzuto, J.M.; Chang, L.C. Potential anti-inflammatory phenolic glycosides from the medicinal plant Moringa oleifera fruits. Bioorganic Med. Chem. 2010, 18, 6598-6602. [CrossRef] 
17. Siddhuraju, P.; Becker, K. Antioxidant properties of various solvent extracts of total phenolic constituents from three different agroclimatic origins of drumstick tree (Moringa oleifera Lam.) leaves. J. Agric. Food Chem. 2003, 51, 2144-2155. [CrossRef]

18. Singh, B.N.; Singh, B.R.; Singh, R.L.; Prakash, D.; Dhakarey, R.; Upadhyay, G.; Singh, H.B. Oxidative DNA damage protective activity, antioxidant and anti-quorum sensing potentials of Moringa oleifera. Food Chem. Toxicol. 2009, 47, 1109-1116. [CrossRef]

19. Sreelatha, S.; Padma, P.R. Protective mechanisms of Moringa oleifera against CCl(4)-induced oxidative stress in precision-cut liver slices. Complementary Med. Res. 2010, 17, 189-194. [CrossRef]

20. Faizi, S.; Siddiqui, B.S.; Saleem, R.; Siddiqui, S.; Aftab, K.; Gilani, A.H. Fully acetylated carbamate and hypotensive thiocarbamate glycosides from Moringa oleifera. Phytochemistry 1995, 38, 957-963. [CrossRef]

21. Mahajan, S.G.; Mehta, A.A. Inhibitory Action of Ethanolic Extract of Seeds of Moringa oleifera Lam. On Systemic and Local Anaphylaxis. J. Immunotoxicol. 2007, 4, 287-294. [CrossRef]

22. Jaiswal, D.; Kumar Rai, P.; Kumar, A.; Mehta, S.; Watal, G. Effect of Moringa oleifera Lam. leaves aqueous extract therapy on hyperglycemic rats. J. Ethnopharmacol. 2009, 123, 392-396. [CrossRef]

23. Mbikay, M. Therapeutic Potential of Moringa oleifera Leaves in Chronic Hyperglycemia and Dyslipidemia: A Review. Front. Pharmacol. 2012, 3, 24. [CrossRef]

24. Lurling, M.; Beekman, W. Anti-cyanobacterial activity of Moringa oleifera seeds. J. Appl. Phycol. 2010, $22,503-510$. [CrossRef]

25. Viera, G.H.; Mourao, J.A.; Angelo, A.M.; Costa, R.A.; Vieira, R.H. Antibacterial effect (in vitro) of Moringa oleifera and Annona muricata against Gram positive and Gram negative bacteria. Rev. Inst. Med. Trop. De Sao Paulo 2010, 52, 129-132. [CrossRef]

26. Sudha, P.; Asdaq, S.M.; Dhamingi, S.S.; Chandrakala, G.K. Immunomodulatory activity of methanolic leaf extract of Moringa oleifera in animals. Indian J. Physiol. Pharmacol. 2010, 54, 133-140.

27. Gupta, A.; Gautam, M.K.; Singh, R.K.; Kumar, M.V.; Rao Ch, V.; Goel, R.K.; Anupurba, S. Immunomodulatory effect of Moringa oleifera Lam. extract on cyclophosphamide induced toxicity in mice. Indian J. Exp. Biol. 2010, 48, 1157-1160.

28. Khor, K.Z.; Lim, V.; Moses, E.J.; Abdul Samad, N. The In Vitro and In Vivo Anticancer Properties of Moringa oleifera. Evid. Based Complementary Altern. Med. 2018, 2018, 1071243. [CrossRef]

29. Madi, N.; Dany, M.; Abdoun, S.; Usta, J. Moringa oleifera's Nutritious Aqueous Leaf Extract Has Anticancerous Effects by Compromising Mitochondrial Viability in an ROS-Dependent Manner. J. Am. Coll. Nutr. 2016, 35, 604-613. [CrossRef]

30. Gismondi, A.; Canuti, L.; Impei, S.; Di Marco, G.; Kenzo, M.; Colizzi, V.; Canini, A. Antioxidant extracts of African medicinal plants induce cell cycle arrest and differentiation in B16F10 melanoma cells. Int. J. Oncol. 2013, 43, 956-964. [CrossRef]

31. Nair, S.; Varalakshmi, K. Anticancer, cytotoxic potential of Moringa oleifera extracts on HeLa cell line. J. Nat. Pharm. 2011, 2, 138.

32. Abd-Rabou, A.A.; Abdalla, A.M.; Ali, N.A.; Zoheir, K.M. Moringa oleifera Root Induces Cancer Apoptosis more Effectively than Leave Nanocomposites and Its Free Counterpart. Asian Pac. J. Cancer Prev. 2017, 18, 2141-2149. [CrossRef]

33. Adebayo, I.A.; Arsad, H.; Samian, M.R. Antiproliferative effect on breast cancer (MCF7) of Moringa oleifera seed extracts. Afr. J. Tradit Complement. Altern. Med. 2017, 14, 282-287. [CrossRef]

34. Tang, J.; Tanoli, Z.U.; Ravikumar, B.; Alam, Z.; Rebane, A.; Vähä-Koskela, M.; Peddinti, G.; van Adrichem, A.J.; Wakkinen, J.; Jaiswal, A.; et al. Drug Target Commons: A Community Effort to Build a Consensus Knowledge Base for Drug-Target Interactions. Cell Chem. Biol. 2018, 25, 224-229. [CrossRef]

35. Verdon, B.; Zheng, J.; Nicholson, R.A.; Ganelli, C.R.; Lees, G. Stereoselective modulatory actions of oleamide on $\operatorname{GABA}(\mathrm{A})$ receptors and voltage-gated $\mathrm{Na}(+)$ channels in vitro: A putative endogenous ligand for depressant drug sites in CNS. Br. J. Pharm. 2000, 129, 283-290. [CrossRef]

36. Sudhahar, V.; Shaw, S.; Imig, J.D. Mechanisms involved in oleamide-induced vasorelaxation in rat mesenteric resistance arteries. Eur. J. Pharm. 2009, 607, 143-150. [CrossRef]

37. Thomas, E.A.; Carson, M.J.; Neal, M.J.; Sutcliffe, J.G. Unique allosteric regulation of 5-hydroxytryptamine receptor-mediated signal transduction by oleamide. Proc. Natl. Acad. Sci. USA 1997, 94, 14115-14119. [CrossRef] 
38. Boger, D.L.; Patterson, J.E.; Jin, Q. Structural requirements for 5-HT2A and 5-HT1A serotonin receptor potentiation by the biologically active lipid oleamide. Proc. Natl. Acad. Sci. USA 1998, 95, 4102-4107. [CrossRef]

39. Kita, M.; Ano, Y.; Inoue, A.; Aoki, J. Identification of P2Y receptors involved in oleamide-suppressing inflammatory responses in murine microglia and human dendritic cells. Sci. Rep. 2019, 9, 3135. [CrossRef]

40. Boger, D.L.; Fecik, R.A.; Patterson, J.E.; Miyauchi, H.; Patricelli, M.P.; Cravatt, B.F. Fatty acid amide hydrolase substrate specificity. Bioorganic Med. Chem. Lett. 2000, 10, 2613-2616. [CrossRef]

41. Lambert, D.M.; Fowler, C.J. The endocannabinoid system: Drug targets, lead compounds, and potential therapeutic applications. J. Med. Chem. 2005, 48, 5059-5087. [CrossRef]

42. Seierstad, M.; Breitenbucher, J.G. Discovery and development of fatty acid amide hydrolase (FAAH) inhibitors. J. Med. Chem. 2008, 51, 7327-7343. [CrossRef]

43. Xu, M.Z.; Lee, W.S.; Kim, M.J.; Park, D.S.; Yu, H.; Tian, G.R.; Jeong, T.S.; Park, H.Y. Acyl-CoA: Cholesterol acyltransferase inhibitory activities of fatty acid amides isolated from Mylabris phalerate Pallas. Bioorganic Med. Chem. Lett. 2004, 14, 4277-4280. [CrossRef] [PubMed]

44. Sullivan, K.D.; Galbraith, M.D. Mechanisms of transcriptional regulation by p53. Cell Death Differ. 2018, 25, 133-143. [CrossRef] [PubMed]

45. McIlwain, D.R.; Berger, T.; Mak, T.W. Caspase functions in cell death and disease. Cold Spring Harb. Perspect. Biol. 2013, 5, a008656. [CrossRef]

46. Edlich, F. BCL-2 proteins and apoptosis: Recent insights and unknowns. Biochem. Biophys. Res. Commun. 2018, 500, 26-34. [CrossRef]

47. Martinou, J.C.; Youle, R.J. Mitochondria in apoptosis: Bcl-2 family members and mitochondrial dynamics. Dev. Cell 2011, 21, 92-101. [CrossRef]

48. Nikoletopoulou, V.; Markaki, M.; Palikaras, K.; Tavernarakis, N. Crosstalk between apoptosis, necrosis and autophagy. Biochim. Biophys. Acta 2013, 1833, 3448-3459. [CrossRef]

49. Silva, M.T. Secondary necrosis: The natural outcome of the complete apoptotic program. FEBS Lett. 2010, 584, 4491-4499. [CrossRef]

50. Al-Asmari, A.K.; Albalawi, S.M.; Athar, M.T.; Khan, A.Q.; Al-Shahrani, H.; Islam, M. Moringa oleifera as an Anti-Cancer Agent against Breast and Colorectal Cancer Cell Lines. PLoS ONE 2015, 10, e0135814. [CrossRef]

51. Vergara-Jimenez, M.; Almatrafi, M.M.; Fernandez, M.L. Bioactive Components in Moringa oleifera Leaves Protect against Chronic Disease. Antioxidants 2017, 6, 91. [CrossRef]

52. Mahdi, H.J.; Khan, N.A.; Mahmud, R.; Asmawi, M.Z.; Vikneswaran, A.; Murugaiyah, L. LC/MS, GC/MS screening and in vivo anti-inflammatory activity of Malaysian Moringa oleifera Lam leaf extracts and fractions against carrageenan -induced paw oedema in rats. J. Innov. Pharm. Biol. Sci. 2017, 4, 48-54.

53. Karthivashan, G.; Tangestani Fard, M.; Arulselvan, P.; Abas, F.; Fakurazi, S. Identification of Bioactive Candidate Compounds Responsible for Oxidative Challenge from Hydro-Ethanolic Extract of Moringa oleifera Leaves. J. Food Sci. 2013, 78, C1368-C1375. [CrossRef]

54. Lin, H.; Zhu, H.; Tan, J.; Wang, H.; Wang, Z.; Li, P.; Zhao, C.; Liu, J. Comparative Analysis of Chemical Constituents of Moringa oleifera Leaves from China and India by Ultra-Performance Liquid Chromatography Coupled with Quadrupole-Time-Of-Flight Mass Spectrometry. Molecules 2019, 24, 942. [CrossRef]

55. Cravatt, B.F.; Prospero-Garcia, O.; Siuzdak, G.; Gilula, N.B.; Henriksen, S.J.; Boger, D.L.; Lerner, R.A. Chemical characterization of a family of brain lipids that induce sleep. Science 1995, 268, 1506-1509. [CrossRef]

56. Bisogno, T.; Sepe, N.; De Petrocellis, L.; Mechoulam, R.; Di Marzo, V. The sleep inducing factor oleamide is produced by mouse neuroblastoma cells. Biochem. Biophys. Res. Commun. 1997, 239, 473-479. [CrossRef]

57. Moon, S.M.; Lee, S.A.; Hong, J.H.; Kim, J.S.; Kim, D.K.; Kim, C.S. Oleamide suppresses inflammatory responses in LPS-induced RAW264.7 murine macrophages and alleviates paw edema in a carrageenan-induced inflammatory rat model. Int. Immunopharmacol. 2018, 56, 179-185. [CrossRef]

58. Zibara, K.; Awada, Z.; Dib, L.; El-Saghir, J.; Al-Ghadban, S.; Ibrik, A.; El-Zein, N.; El-Sabban, M. Anti-angiogenesis therapy and gap junction inhibition reduce MDA-MB-231 breast cancer cell invasion and metastasis in vitro and in vivo. Sci. Rep. 2015, 5, 12598. [CrossRef]

59. Ito, A.; Morita, N.; Miura, D.; Koma, Y.; Kataoka, T.R.; Yamasaki, H.; Kitamura, Y.; Kita, Y.; Nojima, H. A derivative of oleamide potently inhibits the spontaneous metastasis of mouse melanoma BL6 cells. Carcinogenesis 2004, 25, 2015-2022. [CrossRef] 
60. Sodvadiya, M.; Patel, H.; Mishra, A.; Nair, S. Emerging Insights into Anticancer Chemopreventive Activities of Nutraceutical Moringa oleifera: Molecular Mechanisms, Signal Transduction and In Vivo Efficacy. Curr. Pharmacol. Rep. 2020, 6, 38-51. [CrossRef]

61. Van Swearingen, A.E.D.; Sambade, M.J.; Siegel, M.B.; Sud, S.; McNeill, R.S.; Bevill, S.M.; Chen, X.; Bash, R.E.; Mounsey, L.; Golitz, B.T.; et al. Combined kinase inhibitors of MEK1/2 and either PI3K or PDGFR are efficacious in intracranial triple-negative breast cancer. Neuro-Oncol. 2017, 19, 1481-1493. [CrossRef]

62. McLaughlin, R.P.; He, J.; van der Noord, V.E.; Redel, J.; Foekens, J.A.; Martens, J.W.M.; Smid, M.; Zhang, Y.; van de Water, B. A kinase inhibitor screen identifies a dual cdc7/CDK9 inhibitor to sensitise triple-negative breast cancer to EGFR-targeted therapy. Breast Cancer Res. 2019, 21, 77. [CrossRef]

63. Tang, J.; Gautam, P.; Gupta, A.; He, L.; Timonen, S.; Akimov, Y.; Wang, W.; Szwajda, A.; Jaiswal, A.; Turei, D.; et al. Network pharmacology modeling identifies synergistic Aurora B and ZAK interaction in triple-negative breast cancer. NPJ Syst. Biol. Appl. 2019, 5, 20. [CrossRef]

64. Chavez, K.J.; Garimella, S.V.; Lipkowitz, S. Triple negative breast cancer cell lines: One tool in the search for better treatment of triple negative breast cancer. Breast Dis. 2010, 32, 35-48. [CrossRef]

65. Crystal, A.S.; Shaw, A.T.; Sequist, L.V.; Friboulet, L.; Niederst, M.J.; Lockerman, E.L.; Frias, R.L.; Gainor, J.F.; Amzallag, A.; Greninger, P.; et al. Patient-derived models of acquired resistance can identify effective drug combinations for cancer. Science 2014, 346, 1480-1486. [CrossRef]

66. Khan, M.S.S.; Asif, M.; Basheer, M.K.A.; Kang, C.W.; Al-Suede, F.S.; Ein, O.C.; Tang, J.; Majid, A.S.A.; Majid, A. Treatment of novel IL17A inhibitor in glioblastoma implementing 3rd generation co-culture cell line and patient-derived tumor model. Eur. J. Pharm. 2017, 803, 24-38. [CrossRef]

67. He, L.; Tang, J.; Andersson, E.I.; Timonen, S.; Koschmieder, S.; Wennerberg, K.; Mustjoki, S.; Aittokallio, T. Patient-Customized Drug Combination Prediction and Testing for T-cell Prolymphocytic Leukemia Patients. Cancer Res. 2018, 78, 2407-2418. [CrossRef]

Publisher's Note: MDPI stays neutral with regard to jurisdictional claims in published maps and institutional affiliations.

(C) 2020 by the authors. Licensee MDPI, Basel, Switzerland. This article is an open access article distributed under the terms and conditions of the Creative Commons Attribution (CC BY) license (http://creativecommons.org/licenses/by/4.0/). 